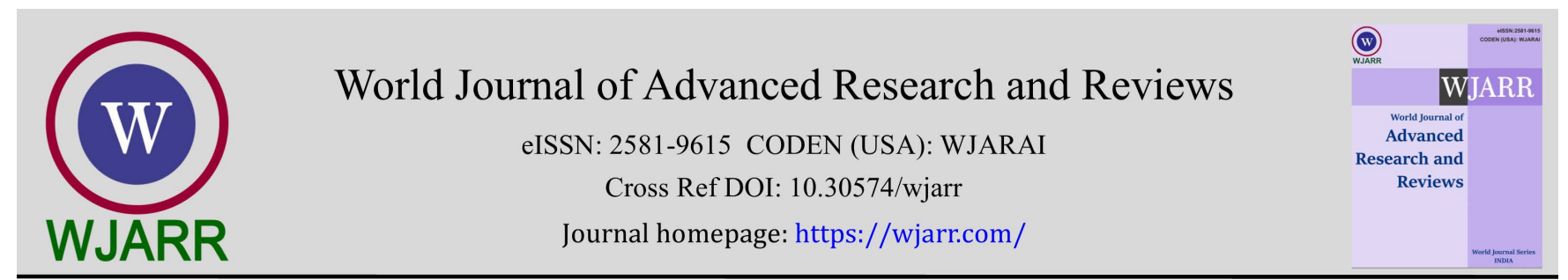

(RESEARCH ARTICLE)

\title{
Use of psychoactive substances and school performance in health students
}

\author{
Guillermo Muñoz- Zurita 1, ${ }^{*}$ and Silvia Bocanegra Carrillo ${ }^{2}$ \\ ${ }^{1}$ Faculty of Medicine of the Meritorious Autonomous University of Puebla (FMBUAP). \\ 2 Emiliano Zapata High School Benemérita Autonomous University of Puebla.
}

World Journal of Advanced Research and Reviews, 2021, 10(03), 273-276

Publication history: Received on 29 April 2021; revised on 10 June 2021; accepted on 13 June 2021

Article DOI: https://doi.org/10.30574/wjarr.2021.10.3.0258

\begin{abstract}
Summary: The consumption of psychoactive substances legal and illegal, is a phenomenon that has been increasing dramatically in the world, which has attracted the attention of international organizations like the United Nations Organization and the World Health Organization. Psychoactive substance use is a real problem that is negatively affecting society, also is affecting consumers in their social, economic and health roles. As a social problem, we can see that several studies and research information reveal the magnitude and trends of use and abuse of such substances in our country.
\end{abstract}

Material and methods: The study was a unicentric and transversal in the student community of "Benemerita Autonomous University of Puebla" medical school in the month of April of this year. A survey was applied based in the Mexican official standard (Norma Oficial Mexicana NOM-028-SSA2-2016) for prevention, treatment and control of addiction, the students are between 18 and 26 years who agreed to participate in the research as voluntary and anonymous people.

Results: The most consumed psychoactive substance in the medical school of the Benemerita Autonomous University of Puebla was caffeine, followed by alcohol and nicotine. In terms of frequency we have $25 \%$ consume these substance daily, $28 \%$ weekly, $18 \%$ monthly and $1 \%$ in exams season. Their consumption motive in the most part of the students $(46 \%)$ was as a part of his life, $23 \%$ do it to improve their performance and $19 \%$ does if for addiction

Keywords: Substances Psychoactive; Consumption; Students; Caffeine; Nicotine; Alcohol

\section{Introduction}

The use of legal and illegal psychoactive substances is a phenomenon that has been increasing dramatically in the world, and to which widely recognized international organizations have drawn attention, such as the United Nations (UN), World Organization of Health (WHO), is a real problem that is negatively affecting humanity, in addition to affecting individual consumers, in their social, economic and health roles [1,2]. As a social problem we can see those various studies and information and surveillance systems account for the magnitude and trends of the use and abuse of such substances in our country [3]. As reported by the national addiction survey in the 2020 version; The use of psychoactive substances has been increasing at an early age, an example is tobacco, with a first-time consumption rate of 13.7 years in the adolescent population, and among the reasons why it is consumed we can include the coexistence, curiosity and improvement in concentration.

\footnotetext{
${ }^{*}$ Corresponding author: Guillermo Muñoz- Zurita

Facultad de Medicina de la Benemérita Universidad Autónoma de Puebla (FMBUAP).

Copyright (C) 2021 Author(s) retain the copyright of this article. This article is published under the terms of the Creative Commons Attribution Liscense 4.0.
} 


\section{Material and methods}

A cross-sectional single-center study was carried out in the student community of the Faculty of Medicine of the Benemerita Autonomous University of Puebla in April 2021. A questionnaire based on the Official Mexican Standard NOM-028-SSA2-2016 was applied. For the prevention, treatment and control of addictions. Inclusion criteria: Registered students of the BUAP School of Medicine aged 18 to 26 years who agreed to participate in the research voluntarily and anonymously. Exclusion criteria: Students who do not belong to the BUAP School of Medicine or who were not willing to take the survey. The survey was made with a total of 13 items, divided into 3 parts, the first part ranges from selecting the psychoactive substances of your choice (caffeine, nicotine, taurine, alcohol, amphetamines, marijuana, and glutamic acid), and the frequency with which they do, the reason or circumstance for which they consume them. The second part of the questionnaire was directed to certain psychoactive substances and the effect that the consumption of said substance generates on them, as well as the amount of it and finally in the third part the students are asked to note on which rating scale is your cumulative average throughout your college life. The survey was applied in the free periods of classes and some when the students were within the classrooms. Descriptive statistics were used to analyze the data obtained through the questionnaire, processing using Microsoft Excel software.

\section{Results}

The study covered a total of 100 students in the health area with ages ranging from 18 to 26 years, with an average age of 20.89 years, 55 are women and 45 are men. With a variability in their semester of study (from 2 nd to 10 th); with a quantity of 12 students of the 2nd semester; 20 of 4th semester; 22 from 6th semester, 30 from 8 th semester; 5 of the 9 th semester and 8 of the 10th semester. Regarding the mention of substances (this because more than 1 option could be marked) we have that: 84 (47\%) of the students ingested caffeine; 61 (33\%) respondents drank alcohol, nicotine was a positive response in 17 (9\%) of the students while taurine was evident in $10(5 \%)$ of the examinees; The claim to marijuana in 3 (2\%) college students is striking. Regarding the frequency, we have that $25 \%$ of students consume this type of substances on a daily basis, $28 \%$ weekly, $18 \%$ monthly, $15 \%$ during exam season and $10 \%$ when they report being "stressed". Figure 2 shows the percentage of the reason for which they consume the substance: $46 \%$ of those interviewed refer to consuming it as part of their life, $23 \%$ for improving their academic performance, 19\% for addiction to it.

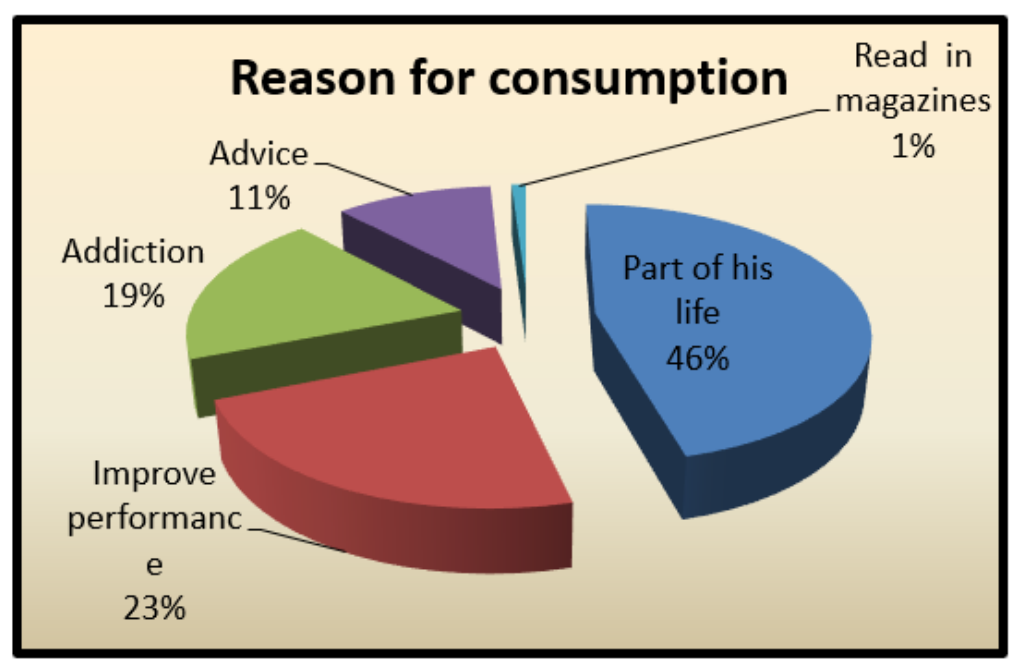

Figure 1 Reason for consumption declared by students in the health area

The second part of the questionnaire includes questions aimed at certain substances, such was the case of nicotine, caffeine and alcohol. With regard to nicotine, a total of 24 smokers were found, of which 22 reported smoking less than 5 cigarettes a day, only 2 students reported smoking between 5 and 10 cigarettes. With these data we obtained the smoking index [14]. and in this case the smoking population turned out to have a smoking index of 0.59 paq / year, said number of packs still does not represent a risk of contracting obstructive pulmonary diseases such as COPD and pulmonary emphysema. A smoking index above 10 already represents a clear risk of establishing any of these pathologies, including cancer as well. Regarding the most notable effect, we have the improvement in concentration declared by $11(46 \%)$ students, as well as insomnia $4(17 \%)$ and euphoria $3(12 \%)$. The next substantial section to review was caffeine, when they were asked about how many cups of coffee they consumed per day, it was found that 
44.94\% (40) ingested 1 cup per day, 42.69\% (38) drank 2 cups per day, $6.74 \%$ (6) tasted 3 cups a day and only $5.61 \%$ (5) declared consuming more than 3 cups a day. It was denoted that the main effect was insomnia in 48.31\% (43) followed by the effect of improving concentration 32.58\% (29), euphoria 7.86\% (7), disinhibition 2.24\% (2) and 8.98\% (8) declared no have no effect with coffee intake. The last substance examined in our research was alcohol; in which asking a question related to how many glasses of alcohol the respondent drinks on a typical day; detecting that $39.34 \%$ (24) ingest 1 to 2 drinks, 29.50\% (18) drink 3-4 drinks, 14.75\% (9) drink 5-6 drinks and 16.39\% (10) drink 7 to 9 drinks . They were also asked if they had ever felt guilty about drinking alcohol; resulting in $75.40 \%$ (41) who have never felt any guilt, 19.67\% (12) reported guilt less than 1 time a month, 8.19\% (5) mentioned guilt once a month, 3.27\% (2) showed guilt a week and only $1.63 \%$ (1) affirm guilt on a daily basis. Regarding the effect caused, we have in the first place disinhibition with 39.34\% (24), followed by euphoria with 39.34\% (19), insomnia with 19.67\% (12) and improvement in concentration with $9.83 \%$ (6).Of the total number of university students surveyed, only 23 (23\%) examined reported consuming the substance in order to improve their academic performance, of the latter only 6 (26.08\%) students have averages of 8.6-9.0; followed by 5 (21.73\%) students with averages of 9.1-9.5 and only 1 (4.34\%) with an average of 9.6-10.0, the rest of interviewees 11 (47.81\%) have an average of 7.5-8.5.

\section{Discussion}

As reaffirmed by the bibliographic sources consulted, we have that the psychoactive substance most consumed by the student community in the health area is caffeine, followed by alcohol and nicotine, we can also see that consumption is not routinely the Medical students tend to consume these substances monthly or weekly, and some others consume them in order to mitigate the stress they are subjected to. We can see that the main reason why medical students consume some psychoactive substance is not precisely to improve their academic performance, but rather that they consume them almost exclusively as part of their life or many times because of the addiction that the substance implicitly causes them. Or imposes. Regarding caffeine, it can be seen that the majority of students (87.63\%) do not consume more than 2 cups of coffee a day, and again it can be seen that the main effects they produce are insomnia and improvement of the concentration, which improve performance. Some studies have also shown that a caffeine consumption of up to $300 \mathrm{mg} /$ day does not constitute a greater risk of myocardial infarction, hypertension, or modification of the plasma levels of cardiovascular risk indicators, such as C-reactive protein and homocysteine, therefore its consumption is not considered counterproductive [15]. Regarding the nicotine data obtained by the 24 students, it was noted that in our study the results are similar to those of the bibliographic sources consulted, the main effect perceived being the improvement in concentration and the insomnia that it causes, said effects they are helpful for better student performance. It should be noted that these college active smokers obtained an average smoking rate of 0.59 paq / year, which fortunately does not yet represent a risk of contracting obstructive pulmonary diseases. Alcohol consumption was not a cause for concern among the student population, it could be seen that the vast majority have a mild consumption, not having a great reason for guilt and compared to the other 2 previous substances, the effect observed in the vast majority was the disinhibition, euphoria and insomnia, not so with the improvement in concentration. As the bibliography confirms, the vast majority of alcohol use has depressant effects on the central nervous system, having a minimal effect as a stimulant. The relationship of the average with the students who declared to use the psychoactive substance to improve academic performance can be seen that a minimum amount of $26.07 \%$ of university students have averages greater than or equal to 9.1, which corresponds to an optimal or regular average.

\section{Conclusion}

The substances most consumed in the student population in the health area are caffeine, nicotine and alcohol, the first 2 having a key effect by improving concentration, and not with the latter, which only exerts a predominant role as a depressant of alcohol. Central Nervous System. These substances are not used solely for the purpose of improving performance, but to improve various situations such as stress, as part of the diet and lifestyle.

\section{Compliance with ethical standards}

\section{Disclosure of conflict of interest}

Authors declare that there is no conflict of interest

\section{Statement of informed consent}

Informed consent was obtained from all individual participants included in the study. 


\section{References}

[1] Organización Mundial de la Salud. Carta de Ottawa para la Prevención de la Salud. Ottawa, Canada. 1986.

[2] Cox TC, Jacobs MR, Leblanc AE, Marshall JA. Drugs and Drug Abuse: A Reference Text. Addiction Research Foundation, Canada. 1983.

[3] Secretaría de Salud. Modificación a la Norma Oficial Mexicana Norma Oficial Mexicana NOM-028-SSA2-2016, Para la prevención, tratamiento y control de las adicciones.

[4] Secretaría de Salud. Encuesta Nacional de Adicciones. Edición. 2011.

[5] Acevedo UM, Arango OL, Blandón ML, Buelvas SL, Carmona VD, Castaño CJ. Consumo de anfetaminas, para mejorar rendimiento académico, en estudiantes de la Universidad de Manizales, 2008. Arch. Med. (Manizales). 2009; 9(1): 44-53.

[6] McCusker R.R; Goldenberg B.A; Cone E.J. Caffeine content of specialty coffees. J. Anal Toxicol. 2003; 27: 520-22.

[7] Segarra R y cols. Efectos esperados y adversos Del consumo de cannabis en sujetos dependientes de los tetrahidrocannabinoides. Trastornos Adictivos. 2006; 8(3): 148-54.

[8] Jiménez TL; Bascarán F.M.T; Fernández; García P.M.P; González P.A; Sáiz M; Bousoño G.M; Bobes G.J. La Nicotina Como Droga. Adicciones. 2004; 16(2): 143-53.

[9] Bolet AM, Socarrás MM. El alcoholismo. Consecuencias y prevención. Rev Cubana Invest Biomed. 2003; 22(1): 25-31.

[10] Laurence LB, Keith LP, Donald KB, Iain LOB. Farmacología y Toxicología del alcohol. "Manual de farmacología y terapéutica Goodman \& Gilman" 12 ${ }^{\text {a }}$ Ed Mc Graw Hill. 2011; 629-45.

[11] Caballero ML. Adicción a cocaína: Neurobiología Clínica, Diagnóstico Y tratamiento.2005; Delegación Del Gobierno para el Plan Nacional sobre Drogas. Madrid España. 23.

[12] Arguedas G; Garnier M; Willy Hong W; Miranda Ch.Z; Rodríguez G. Aspectos médico-legales de los patrones de consumo de bebidas energéticas por parte de los estudiantes de medicina de Segundo año de la Universidad de Costa Rica. Med. Leg. Costa Rica. 2012; 29(1): 23-33.

[13] Consultado el 18 de Marzo de. 2013.

[14] Hernández L, Cuñado JO, Amaya GMJ. Conocimiento del índice total de paquetes/año como medida del hábito de fumar por parte de los clínicos de un servicio de medicina interna" Med Clin, Barc. 2003; 121(9): 359.

[15] Valenzuela BA. El café y sus efectos en la salud cardiovascular y en la salud materna. Rev Chil Nutr. 2010; 37(4): 514-23. 